\title{
Kálium-migráció vizsgálata káliföldpáttal kezelt gyökérközegben
}

\author{
PÁRTAY GÉZA, RAJKAINÉ VÉGH KRISZTINA és LUKÁCS ANDRÁS
}

MTA Talajtani és Agrokémiai Kutatóintézet, Budapest

A talajban a K-felvehetőséget elsősorban a talaj ásványösszetétele, a talaj ásványainak mállási foka, a szilárd fázisból a talajoldatba történő oldódás és a kinetikai jellemzők határozzák meg. A nem K-trágyázott talaj K-állapota nemcsak az anyakőzet minőségétől függ, hanem mállásának egymást követő szakaszaiban a különböző mállási termékek hatására változik (PÁRTAY, 1971).

A talaj ásványi K-forrásai a csillámok és a földpátok. A homok- és iszapfrakciók 5-25\%-ban, az agyag max. 5\%-ban tartalmaz földpátokat. A földpátok K-leadása jóval lassúbb, mint a csillámoké (SzENDREI, 1994).

A csillámok és földpátok mállása során - K felszabadulása mellett - másodlagos ásványok jönnek létre (SPARKS \& HUANG, 1985; SPARKS, 1987). Ezek megköthetik a növények számára felvehető K-mennyiség egy részét és ez az ún. nem kicserélhető K-készlet (NKK) növekedéséhez vezet. A rétegközi kálium leadása a kristályszerkezet összeomlásához vezethet. Az egyes K-formák jelentősége a talaj ásványi összetételének függvénye. Az NKK föleg az agyagásványokban (illit, klorit, ásványtársulásukban szmektit, vermikulit) kötött. Egyensúlyban van az agyag és szerves kolloidok negatív töltésü helyein adszorbeálódott kicserélhető káliummal (KK). CSILLAG és munkatársai (2005) a gyökérkörnyezetben is tapasztalható pH-csökkenés hatására jelentős K-koncentráció növekedést mutattak ki talaj-földpát keverékek folyadékfázisában. A gyökérkörnyezetben a növény nemcsak a talajoldatban oldott és az oda a KK-készletből gyorsan pótlódó káliumot veszi fel, hanem mobilizálja az NKK egy részét (VÉGH \& FÜLEKY, 2004), sőt, a talaj ásványainak mállását elősegítve, azok K-tartalmát is (HINSINGER, 1998; SRINIVASA RAO et al., 2000). A növényi K-kivonás hatására az elsődleges ásványokból feltáródó, talajban maradó kálium a talaj NKK-, ill. KK-frakcióit gazdagítja.

Célunk a talaj-növény rendszerben természetes ásványból származó kálium forgalmának tanulmányozása volt, elsősorban az ásványi összetételre gyakorolt hatások szempontjából. Megvizsgáltuk a bányatermék ortoklász $\left(\mathrm{KAlSi}_{3} \mathrm{O}_{8}\right)$ őrlemény hatását a talajra, a gyökérzetre és a növény K-felvételére, a K-forgalomra és az agyagásványokra. Feltételezésünk szerint: 1. a gyökértevékenység elősegíti a Kföldpát feltáródását, 2. a nagymennyiségü K-bevitel kimutatható hatást gyakorol a

Postai cím: PÁRTAY GÉZA, MTA Talajtani és Agrokémiai Kutatóintézet, 1022 Budapest, Herman Ottó út 15.E-mail: partayg@t-online.hu 
K-oldódásra, ill. megkötődésre, 3. az ortoklász bányatermékkel a rendszerbe bevitt ásványok sorsa követhető a gyökérközegben és a K-forgalomra gyakorolt hatásuk kimutatható.

Dolgozatunkban elsősorban a kálium feltételezett migrációjának a talajásványokra gyakorolt hatásával foglalkozunk, amit röntgendiffraktométeres vizsgálatokkal tanulmányoztunk. Az elektronmikroszkópos vizsgálatokkal - különbözö módszerekkel és eszközökkel - e migrációt befolyásoló topográfiai vonatkozást ismertetjük.

\section{Anyag és módszer}

A barna erdőtalaj (Somogysárd) 10-20 cm közötti szántott rétegéből vett minta röntgendiffrakciós vizsgálatával mintegy $30 \%$ kevert rácsszerkezetủ agyagásványt

1. táblázat

A kísérleti talaj főbb kémiai és fizikai tulajdonságai

\begin{tabular}{|c|c|c|c|c|c|c|c|c|}
\hline \multicolumn{2}{|c|}{$\mathrm{pH}$} & \multirow{2}{*}{$\begin{array}{l}\mathrm{H}, \\
\%\end{array}$} & \multirow{2}{*}{$\begin{array}{c}\text { T-érték } \\
\mathrm{cmol} \cdot \mathrm{kg}^{-1}\end{array}$} & KK & NKK & \multirow{2}{*}{$\begin{array}{c}\mathrm{Tfs} \\
\mathrm{g} \cdot \mathrm{cm}^{-3}\end{array}$} & $<0,02$ & $<0,002$ \\
\hline $\mathrm{H}_{2} \mathrm{O}$ & $\mathrm{KCl}$ & & & \multicolumn{2}{|c|}{$\mathrm{mg} \cdot \mathrm{kg}^{-1}$} & & \multicolumn{2}{|c|}{ mm (tömeg \%) } \\
\hline 6,1 & 5,3 & 1,5 & 7,2 & 70,5 & 684,7 & 1,56 & 21,0 & 9,5 \\
\hline
\end{tabular}

Megjegyzés: H: humusztartalom; T-érték: kationcserélő kapacitás; KK: kicserélhető Ktartalom; NKK: nem kicserélhető káliumtartalom; Tfs: térfogattömeg; $<0,02$ : iszapfrakció + agyagfrakció; <0,002: agyagfrakció

mutattunk ki. Feltételezve, hogy a kevert rácsszerkezet alkalmas arra, hogy az ortoklászból kiváló nagy mennyiségủ szabad káliumion a rácsszerkezet hibahelyein megkötődjék, a talajt tovább tanulmányoztuk rizomonolit-kísérlet keretében.

A talaj alapvizsgálati adatait az 1. táblázat tartalmazza.

A kálium ionrádiusza, ionpotenciálja, magas koncentrációja valószínủvé tette kötődését az ásványok hibahelyeihez. Káliumforrásként ortoklász-tartalmú, előzetesen golyósmalomban örölt, $<100 \mu \mathrm{m}$ szemcseátméröjü, norvég eredetü káliföldpátot használtunk. (Jelzése: NORFLUX 100, NORTH CAPE POTASSIUM FELDSPAR, katalógus száma: EN 6354). A minta ortoklász és albit 80-20\%-os keveréke.

A rizomonolit kísérletekhez $15 \times 15 \times 35 \mathrm{~cm}$ nagyságú, átlátszó plexi oszlopokat - rizomonolitokat - készíttettünk. A rizomonolitok oldalaira $1 \mathrm{~cm}$-es négyzethálót rajzoltunk a gyökérsürüség meghatározása céljából. Az oszlopokba a talphoz kivezetöcsövet helyeztünk az esetleg pangó víz elvezetésére. A gyökérközeget fóliatakarással óvtuk a fénytől. Az oszlopot a talpától számított $15 \mathrm{~cm}$ magasságig mosott kvarchomokkal (gyártó: REANAL) töltöttük meg. Erre műanyag szitaszövetet helyeztünk a talajmigráció gátlására. A következő réteg a vizsgálandó $4 \mathrm{~kg}$ tömegü légszáraz, $0 \%, 25 \%$ és $50 \%$ földpátot tartalmazó talaj:földpát keverék volt (2. táblázat), amelybe a növény megfelelő P-ellátottságának biztosítása érdekében szuperfoszfát-mütrágyát kevertünk $500 \mathrm{mg} \mathrm{P} / \mathrm{kg}$ talaj:földpát keverék arányban. A talaj-földpát keverék felszínére $6 \mathrm{~cm}$ magasságban kvarchomokot rétegeztünk. A 
2. táblázat

A rizomonolit-kísérlet kezelései és jelzésük

\begin{tabular}{|c|c|c|c|c|}
\hline \multirow{2}{*}{$\begin{array}{c}(1) \\
\text { Földpát } \\
\%\end{array}$} & $\begin{array}{c}(2) \\
\text { Növény } \\
\text { nélkül }\end{array}$ & A-sorozat & B-sorozat & C-sorozat \\
\cline { 3 - 5 } & 1 & $1 \mathrm{~N}$ & $4 \mathrm{~N}$ & $7 \mathrm{~N}$ \\
0 & 2 & $2 \mathrm{~N}$ & $5 \mathrm{~N}$ & $8 \mathrm{~N}$ \\
25 & 3 & $3 \mathrm{~N}$ & $6 \mathrm{~N}$ & $9 \mathrm{~N}$ \\
\hline 50 & &
\end{tabular}

növényes sorozatokban az oszlopokba 5 szem kukoricamagot (MARATON, MARTONVÁSÁR) vetettünk, majd kelés után 3 növényre egyeltünk.

A gyökérközeg nedvességtartalma alapvetően befolyásolja a növény $\mathrm{K}$ felvételét meghatározó folyamatokat: a növény növekedési sebességétől függő Kigényét (KANT et al., 2005), a gyökérzet növekedését és a talajban a gyökérfelületre irányuló diffúzív K-transzport sebességét (VÉGH \& FÜLEKY, 2004). A kukorica vízfogyasztása a kísérlet során a tenyészidő átlagában növényenként kb.70 g/nap volt. A megfelelő vízellátottság érdekében a növényes oszlopokat naponta ioncserélt vízzel öntöztük, a növény nélkülieket pedig szükség szerint úgy, hogy a nedvességtartalom lehetőség szerint a növényes rizomonolitok talajának nedvességértékeit közelítse. A talajnedvesség-értékek napi menetét a rizomonolitok talajába épített TDR-szondákkal ellenőriztük.

Hetenként, összesen 4 alkalommal, $105 \mathrm{mg}$ nitrogént tartalmazó $\mathrm{NH}_{4} \mathrm{NO}_{3}$ - oldatot adtunk az oszlopokhoz. A további tápanyag-utánpótlás K-mentes makro- és mikroelem-tartalmú tápoldat („Long Ashton formula”) (SUTCLIFFE \& DENNIS, 1981) adagolásával történt.

A tesztnövényeket virágzásig neveltük, majd az oszlopból eltávolítottuk, a hajtás és gyökérzet száraz tömegét és K-tartalmát meghatároztuk. Az A- és C-sorozat oszlopaiból külön választva mintáztuk a talaj alsó és felső rétegét, valamint az alsó homokágyat, továbbá vizes, ill. ammónium-acetátos kivonatuk K-tartalmát ICP spektrometriás módszerrel meghatároztuk.

A növényes oszlopokban a kísérletet háromszor lefolytattuk (2. táblázat A-, B-, $\mathrm{C}$-sorozat). Az A-sorozat után a rizomonolitok különböző rétegeit eltávolítottuk, mintáztuk, majd a kísérletet új bekeveréssel, újra beállítottuk (B-sorozat). A Bsorozat után a növényeket a rizomonolitból eltávolítottuk és a B-sorozat gyökérközegébe P-trágyázást követően új magot vettetünk (C-sorozat). Ily módon ugyanabban a gyökérközegben két kukoricanemzedéket neveltünk fel annak érdekében, hogy a növény K-kivonása a gyökérközeg K-tartalmát minél nagyobb mértékben kimerítse. A növény nélküli sorozat bolygatatlanul maradt a kísérlet végéig.

$\mathrm{Az}$ ásványi történések vizsgálatára pásztázó elektronmikroszkópos (PEM) (PÁRTAY, 1993), transzmissziós elektron mikroszkópos (TEM) (DóDONY, 1993) és röntgendiffrakciós (Rtg) (KÁLMÁN, 1993) módszert alkalmaztunk. A PEM-, TEMfelvételek értékelésével azokat a topográfiai állapotokat mutattuk be, melyek előse- 
gíthetik a különböző rendezettségủ ásványtársulások létrejöttét. A röntgenvizsgálatokat pedig a közberétegződések variációinak azonosítása céljából végeztük.

\section{Eredmények és értékelés}

A földpátkeverék jellemzöi

A kimosódás jelenségének tisztázására a földpátból a Fritsch-féle malom achát mozsarában 10, 30, 45 és 60 perces örleményt készítettünk. A mechanikai elemzés (3. táblázat) kimutatta, hogy már az eredeti keverék szemcseátmérője 60 mikro-

3. táblázat

A földpátkeverék szemcseösszetétele (\%)

\begin{tabular}{|l|c|c|c|c|c|c|c|}
\hline \multirow{2}{*}{\begin{tabular}{c} 
Minta \\
\cline { 2 - 8 }
\end{tabular}} & \multicolumn{7}{|c|}{ (2) Szemcseméret, mm } \\
\cline { 2 - 8 } & $>0,25$ & $\begin{array}{c}0,25- \\
0,05\end{array}$ & $\begin{array}{c}0,05- \\
0,02\end{array}$ & $\begin{array}{c}0,02- \\
0,01\end{array}$ & $\begin{array}{c}0,01- \\
0,005\end{array}$ & $\begin{array}{c}0,005- \\
0,002\end{array}$ & $<0,002$ \\
\hline a) Eredeti & 0,09 & 13,65 & 41,58 & 21,54 & 11,94 & 7,84 & 3,36 \\
b) Örölt & 0,09 & 14,19 & 37,77 & 21,20 & 12,63 & 8,45 & 5,67 \\
\hline
\end{tabular}

4. táblázat

A barna erdőtalaj- és a 30 (a), ill. 60 (b) percig örölt földpátminták elemtartalma $\left(\mathrm{mg} \cdot \mathrm{kg}^{-1}\right)$

\begin{tabular}{|c|c|c|c|c|c|c|}
\hline \multirow{3}{*}{$\begin{array}{l}(1) \\
\text { Elem }\end{array}$} & \multicolumn{3}{|c|}{ (2) Vizes kivonat } & \multicolumn{3}{|c|}{ (5) $2 \mathrm{~mol} / \mathrm{L} \mathrm{HNO}_{3}$ kivonat } \\
\hline & \multirow{2}{*}{$\begin{array}{c}\text { (3) } \\
\text { Talaj }\end{array}$} & \multicolumn{2}{|c|}{ (4) Földpát } & \multirow{2}{*}{$\begin{array}{c}\text { (3) } \\
\text { Talaj }\end{array}$} & \multicolumn{2}{|c|}{ (4) Földpát } \\
\hline & & $\mathrm{a}$ & $\mathrm{b}$ & & $\mathrm{a}$ & $\mathrm{b}$ \\
\hline $\mathrm{Ca}$ & 70,55 & 2,07 & 2,93 & 1785,4 & 194,92 & 196,37 \\
\hline$K$ & 14,65 & 106,01 & 109,33 & 580,8 & 1073 & 1136 \\
\hline $\mathrm{Mg}$ & 14,13 & 0,47 & 0,62 & 1179,6 & 30,89 & 29,91 \\
\hline $\mathrm{Na}$ & 17,92 & 66,45 & 66,23 & 54,84 & 330,8 & 331,2 \\
\hline $\mathrm{Si}$ & 10,61 & 13,99 & 21,22 & 1463 & 564,6 & 509 \\
\hline
\end{tabular}

méter alatti érték, továbbá azt, hogy az őrlés a szemcseméretben jelentős változást nem okozott.

Az örlemények elemtartalmát 1:5 arányú vizes kivonatban és 2 mol/l-es salétromsavas kivonatban ICP spektrometriás módszerrel határoztuk meg (BUZÁs et al., 1998) (4. táblázat).

A káliföldpát vizes kivonatában a K-tartalom közel azonos volt 30 és 60 perces őrlés után, így az örlés időigénye felére volt csökkenthető. A kísérletünk eredményeit leginkább befolyásoló öt elem a $\mathrm{Ca}, \mathrm{K}, \mathrm{Mg}, \mathrm{Na}, \mathrm{Si}$. Mennyiségi sorrendjük a vizes kivonatban:

Talaj esetében: $\mathrm{Si}<\mathrm{K}=\mathrm{Mg}<\mathrm{Na}<\mathrm{Ca}$;

Földpát esetén: $\mathrm{Mg}<\mathrm{Ca}<\mathrm{Si}<\mathrm{Na}<\mathrm{K}, 30$ és 60 perces örlés után egyaránt. 
FREDERICKSON (1951) szerint a szilikátok mállásakor azok Na-, ill. K-tartalma oldatba megy. Málláskor a káliföldpát azért mutatkozik ellenállóbbnak, mint a plagioklász, mert a földpátokban a kálium koordinációs száma (10) nagyobb, mint a nátriumé és a kalciumé (6). Így a káliföldpát a felszíni csekély hőmérsékletnek megfelelőbb energia-állapotban van. A vízben oldott kálium erős diszperzióját arra lehet visszavezetni, hogy a $\mathrm{Na}, \mathrm{K}, \mathrm{Mg}$, Ca sorozatból a káliumnak legkisebb a vízhez mért ionrádiusza, így a legkönnyebben jut be a kristályrácsba.

\section{A rizomonolit-kísérlet eredményei}

A káliföldpát-kezelés nem volt hatással sem a kukoricahajtás szárazanyaghozamára, sem a gyökértömegre. Jelentősen befolyásolta viszont a tesztnövény K-

\section{5. táblázat}

Növény által kivont kálium, a talaj vizes kivonatban mért $\left(\mathrm{H}_{2} \mathrm{O}-\mathrm{K}\right)$ és kicserélhető (KK) káliumtartalma a kísérlet végén $\left(\mathrm{mg} \cdot \mathrm{kg}^{-1}\right.$ talaj-földpát keverék)

\begin{tabular}{|c|c|c|c|c|c|c|}
\hline \multirow{2}{*}{$\stackrel{(1)}{\text { Kezelés }}$} & \multirow[b]{2}{*}{$\begin{array}{c}(2) \\
\text { Növény } \\
\text { által kivont } \\
\mathrm{K}\end{array}$} & \multicolumn{2}{|c|}{ (3) Talaj K-tartalma } & \multirow[b]{2}{*}{$\begin{array}{c}\text { (6) } \\
\text { Kezelés } \\
\text { és talaj- } \\
\text { szint }\end{array}$} & \multicolumn{2}{|c|}{ (3) Talaj K-tartalma } \\
\hline & & $\begin{array}{c}(4) \\
\text { vizes } \\
\text { kivonatban } \\
\text { mért }\end{array}$ & $\begin{array}{l}\text { (5) } \\
\text { kicserél- } \\
\text { hető }\end{array}$ & & $\begin{array}{c}(4) \\
\text { vizes } \\
\text { kivonatban } \\
\text { mért }\end{array}$ & $\begin{array}{l}\text { (5) } \\
\text { kicserél- } \\
\text { hető }\end{array}$ \\
\hline $1 \mathrm{~N}$ & 76,2 & 12,5 & 49,8 & $1-$ felső & 12,0 & 68,9 \\
\hline $2 \mathrm{~N}$ & 207,8 & 16,3 & 48,4 & 1 - alsó & 17,3 & 66,7 \\
\hline $3 \mathrm{~N}$ & 99,5 & 19,0 & 74,9 & $2-$ felső & 43,2 & 105,2 \\
\hline $4 N+7 N$ & 103,2 & 5,2 & 42,4 & 2 - alsó & 31,0 & 119,3 \\
\hline $5 \mathrm{~N}+8 \mathrm{~N}$ & 136,7 & 5,2 & 31,2 & $3-$ felső & 57,5 & 158,0 \\
\hline $6 \mathrm{~N}+9 \mathrm{~N}$ & 201,8 & 8,5 & 52,5 & 3 - alsó & 48,2 & 171,5 \\
\hline
\end{tabular}

Megjegyzés: a kezeléseket lásd a 2. táblázatban

felvételét (5. táblázat) és a gyökérzet hossznövekedését. A káliföldpát-kezelt talajokban a gyökérsürüség sokkal kisebb volt, mint a kezeletlen talajban; az $1 \mathrm{~N}-, 2 \mathrm{~N}$ és 3N-kezelésben 453, 280 és $200 \mathrm{~cm} / \mathrm{cm}^{2}$ (A-sorozat, 8-hetes növények adatai). Tehát a nagymennyiségü földpát hozzáadása a talajhoz a gyökér hossznövekedését gátló gyökérkörnyezet kialakulásához vezetett. Ez a fizikai környezet romlását is jelentheti: a földpátkezelésekben a közeg tömődöttebb volt, ugyanakkor lelassult az öntözővíz beszivárgása és jelentősen csökkent a vízvezető képesség és levegőzés. LUKÁCS és munkatársai (2005) a tesztnövények szöveteiben a gázfázis összetételét vizsgálták és a $\mathrm{O}_{2}: \mathrm{CO}_{2}$ arány nagymértékű változását mutatták ki, ami egyértelmüen jelzi az 50\% földpátkezelés kedvezőtlen hatását.

A tesztnövények (hajtás+gyökérzet) által a talajból összesen kivont kálium mennyiségét, valamint a kísérletek végén mintázott talaj-földpát keverékek vizes kivonatban mért és kicserélhetö K-tartalmát az 5. táblázatban mutatjuk be. A kicserélhető K-tartalmat az ammónium-acetát kivonható kálium (RÉDLYNÉ, 1998) és a vizes kivonatban mért kálium különbségeként határoztuk meg. A növényes oszlo- 
pok gyökérközegéből ehhez a vizsgálathoz átlagmintát kevertünk, míg a növény nélküli kezelésekben a talaj-földpát keverék felső és alsó szintjét külön vizsgáltuk, mivel itt a keveréken belüli vertikális eloszláskülönbségek kialakulására is számítottunk. Meghatároztuk a rizomonolitokban a talaj-földpát keverék alá rétegzett homokba a gyökérközegböl kimosódott, ill. a gyökérzet által a talaj alatti szintbe szállított kálium mennyiségét is. A rizomonolitok alsó homokágyában mért ammónium-acetát kivonható $\mathrm{K}$-tartalomra (a vízoldható és a kicserélhető $\mathrm{K}$ összege) a növekvő földpátadagok sorrendjében növényes edényekben 17,8 , és $19,6 \mathrm{mg} \cdot \mathrm{kg}^{-1}$, a növény nélküli edényekben 19,7 és 41,7 mg·kg ${ }^{-1}$ közötti értékek adódtak.

Az 5. táblázatban a B- és C-sorozat növényi kivonását összegeztük, mivel a gyökérközeget a B- és C-sorozat között nem cseréltük és K-tartalmát csak a C-sorozat növényeinek levágása után határoztuk meg. Ilyen módon összegeződött a két, egymás után nevelt növénynemzedék gyökérközegre gyakorolt hatása, amint azt a vízoldható és kicserélhető káliumra vonatkozóan az 5. táblázatban bemutatjuk.

A növények jóval több káliumot vontak ki, mint a kiindulási talaj KK készlete. A kukorica K-felvétele minden földpátkezelésben jelentősen csökkentette a gyökérközeg vízoldható és kicserélhető K-tartalmát, míg a gyökérközegből az alsó homokrétegbe került kálium mennyisége közel azonos volt. A két, szukcesszíve nevelt kukoricanemzedék K-felvétele következtében igen alacsony szintre csökkent kicserélhető K-mennyiség a káliumnak csak lassú utánpótlódását tette lehetővé a talajoldatba, amit a vízoldható K-értékek kis értékei jeleznek. A növény nélküli kezelésekben mind a vízoldható, mind a kicserélhető K-tartalom jelentősen emelkedett a földpátadagok hatására. A középvonal feletti és alatti rétegek vízoldható és kicserélhető K-értékei alapján feltételezhetjük, hogy földpát hatására az alsó szintekben a K-forgalom a megkötődés irányába tolódott el (v. ö. 6. táblázat). A kálium vertikális elmozdulását az öntözővíz gravitációs mozgása tovább erősítette.

\section{Pásztázó elektronmikroszkópos (PEM) vizsgálatok}

A PEM vizsgálatokat úgy végeztük, hogy a mintán lévő mikrorepedés mentén szétvált talajrögöt rögzítettük a mintatartóra úgy, hogy a repedés fala a leképező sugárra merőleges legyen. Mindkét felvételünk egy-egy mikrorepedés falának részletét mutatja. A vizsgáló müszer ISI SEM II. Felbontóképessége kisebb mint $7 \mathrm{~nm}$. A felvételek felső széle a talaj közeli rész. A felvételeket és magyarázatukat a 2. és a 3. ábrán mutatjuk be (PÁRTAY, 1980).

\section{Transzmissiós elektronmikroszkópos (TEM) vizsgálatok}

KOCH (1985) feltárásaiból KOCH és SzTRÓKAY (1967) meghatározásai alapján ortoklász törmelékböl TEM-vizsgálatokat végeztünk. A sorozatfelvételekböl kiválasztott kép (1. ábra) valószínúleg a feltárás közben lepattant pengeszerü kristálytöredéket ábrázol. Esetünkben a vizsgáló müszer TESLA BS 242, az ásványtörmeléket szitálással, majd achát mozsárban finomítottuk. 0,01 N NH $\mathrm{N}_{4} \mathrm{OH}$-os szuszpenzióból kollódium hordozó hártyára cseppentettünk, száradás után Palládium gözöléssel árnyékoltunk. 


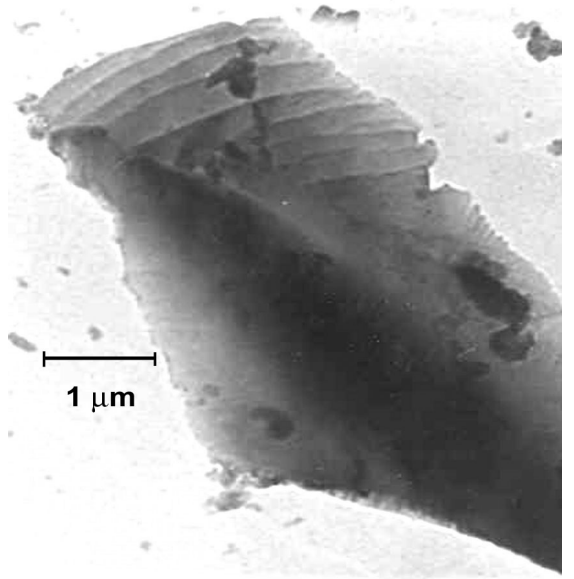

1. ábra

Ortoklász kristály

A nagy felbontású TEM-minták készítéséhez kisebb, mint 2 mikronos pormintából szuszpenziót készítettünk. Ezt a szuszpenziót spektrográf szénből készített hártyán szárítottuk, majd a mintát 25 fokos szögből ugyancsak szénnel árnyékoltuk. Az árnyékolás szögének tangenséböl és a minta árnyéka hosszának szorzatából következtetni tudunk a minta magasságára (PÁRTAY, 1973).

A felvételeket JEOL TEM 120 -as készülékkel végeztük. Jellemző paraméterei a felvételek értelmezéséhez: felbontóképessége - point-to-point $-0,2 \mathrm{~nm}$, végnagyítása 200.000-szeres. A bemutatott képeken az eredeti elektronoptikai nagyítást mikronban közöljük. Az ásványok meghatározását részben saját archívumunk, részben BEUTELSPACHER és VAN DER MAREL (1968), valamint HENNING és STÖRR (1986) atlasza adatainak felhasználásával végeztük. A felvételeket és magyarázatukat a 4., 5. és 6. ábrán mutatjuk be.

\section{Röntgendiffrakciós (RTG) vizsgálatok}

A vizsgálatokat részben pormintából végeztük kezeletlen talajon, részben ebből a talajból vett $<2$ mikronos frakción. A $<2$ mikronos frakcióból orientált, $550{ }^{\circ} \mathrm{C}$ on, valamint etilénglikollal kezelt preparátumot is készítettünk. A vizsgálatokat DRON 2.0 diffraktométerrel $\mathrm{Cu} \mathrm{K}$ alfa sugárzás és $\mathrm{Ni}$ szürés mellett végeztük. A rácsparamétereket a Miller-index és a szerzők közlései alapján ismertetjük. Az ásványok meghatározására az ASTM katalógus- és kártyaregisztert használtuk. Más forrásmunkát külön jelöljük. A csúcsok intenzitásának megjelölésére a szerzők vagy a tízes osztatú $100-10$-ig, vagy a hatos osztatú VS-S-ig terjedő rendszert használják. Dolgozatunkban a tízes rendszert alkalmazzuk. Az idézetekben megtartjuk a szerző jelölését. 


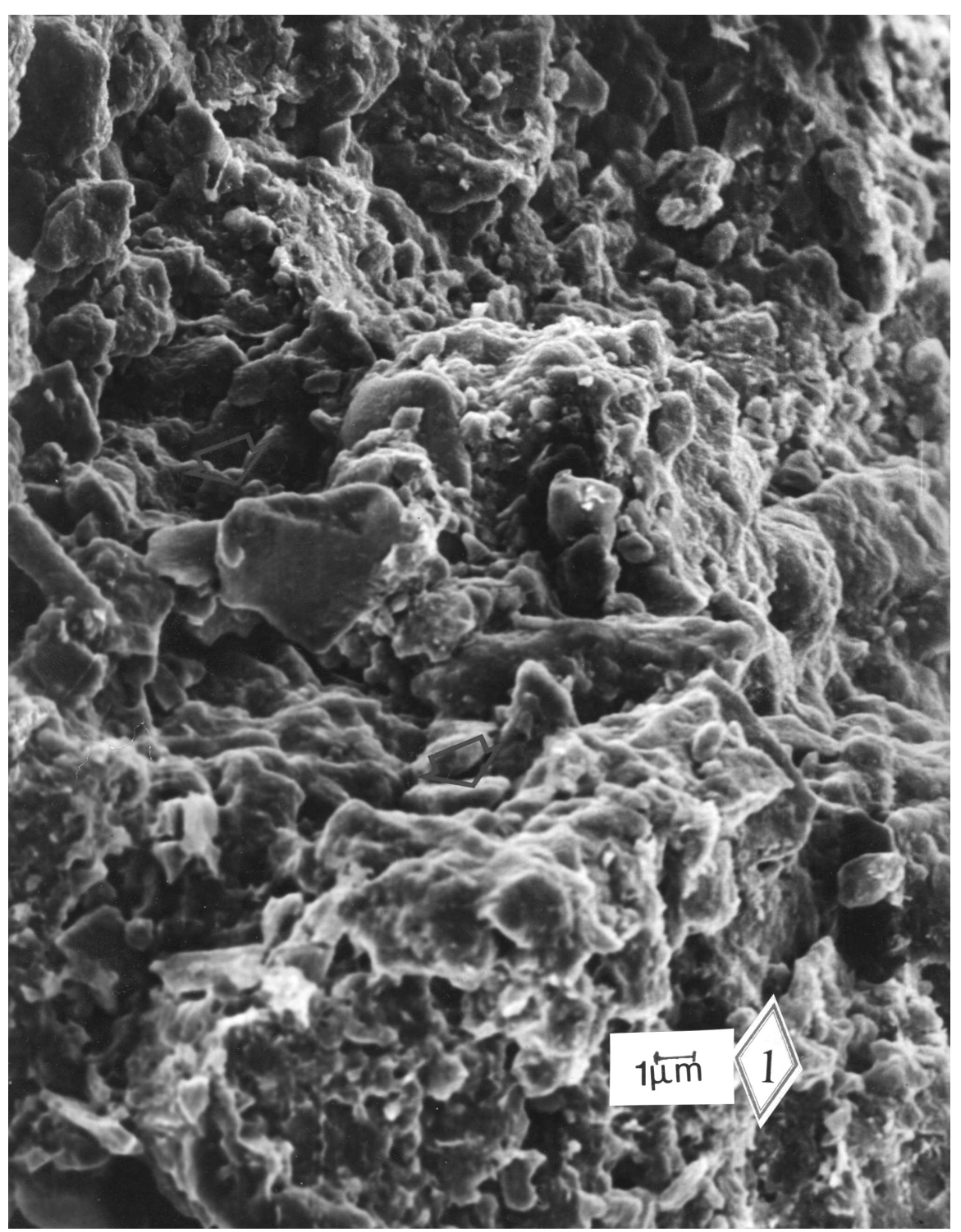

2. ábra

\section{PEM-felvétel}

A 2. ábrán erősen kimosódott résfalat látunk. A kristályos képletek befolyó víz hordaléka által lesimítottak, karakterüket elvesztették, nem meghatározhatók. A képletek függőlegesen orientáltak, cementálódtak. Egy összeragadt ásványkonglomerátum - mint egy erkély mélyen benyúlik a résbe. Felső részén a képletek legömbölyítettek, míg az alsó részén csepegés nyomai látszanak. Az uralkodó ásvány illitnek határozható meg. 


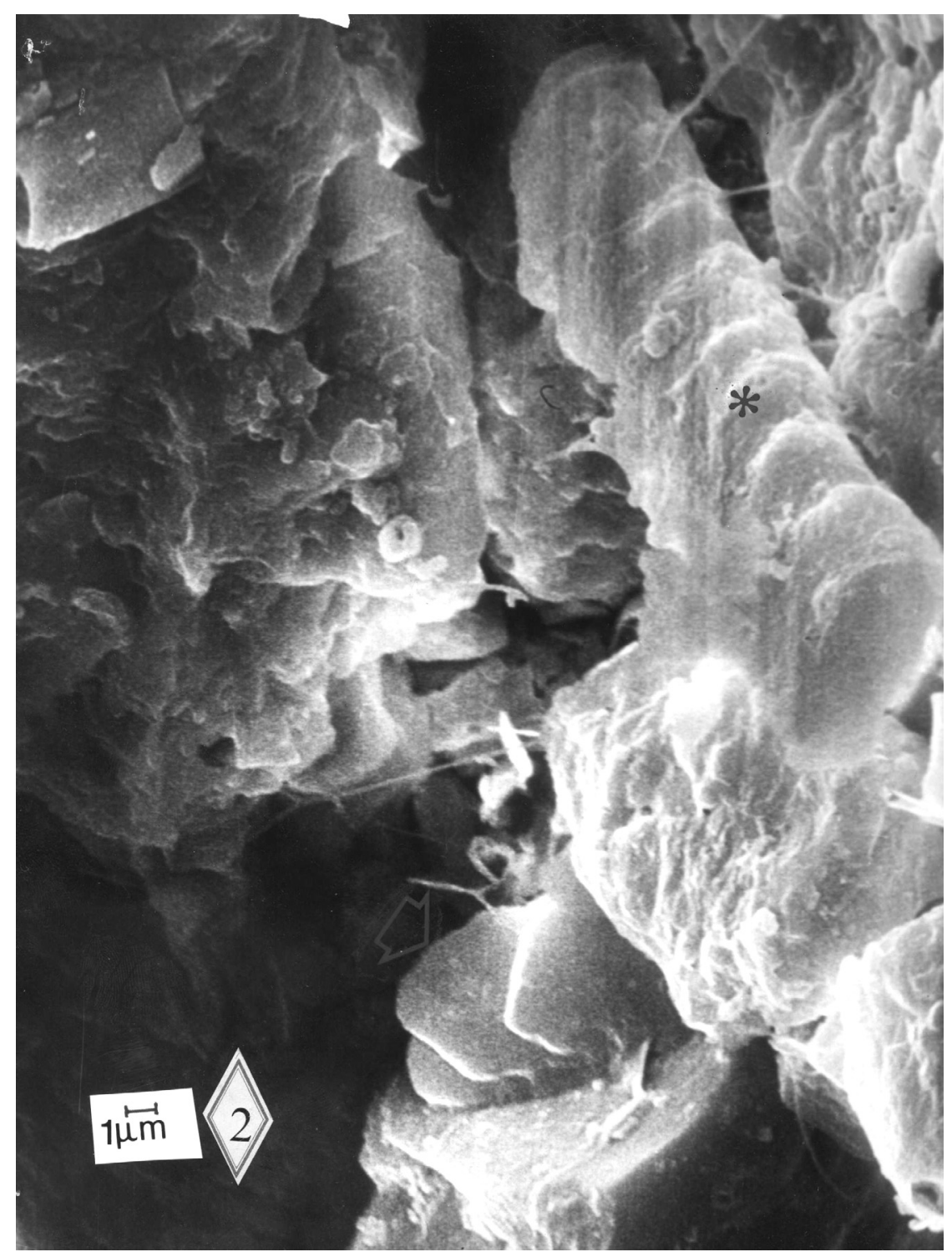

\section{3. ábra}

\section{PEM-felvétel}

A 3. ábrán egy mikrorepedés hosszában szelt ketté egy üregben végződő krotovinát. A járaton keresztül hordalék sodródott az üregbe, mely valószínúleg az üreg falából kiálló kvarckristályon fennakadt. Két sima és egy típusosan törött felszín határolja. Felső lapjára három málló kaolinitkristály, valamint egy csillám-illit összetételü konglomerátum támaszkodik. A talajgombák jellemzői még a képnek. 


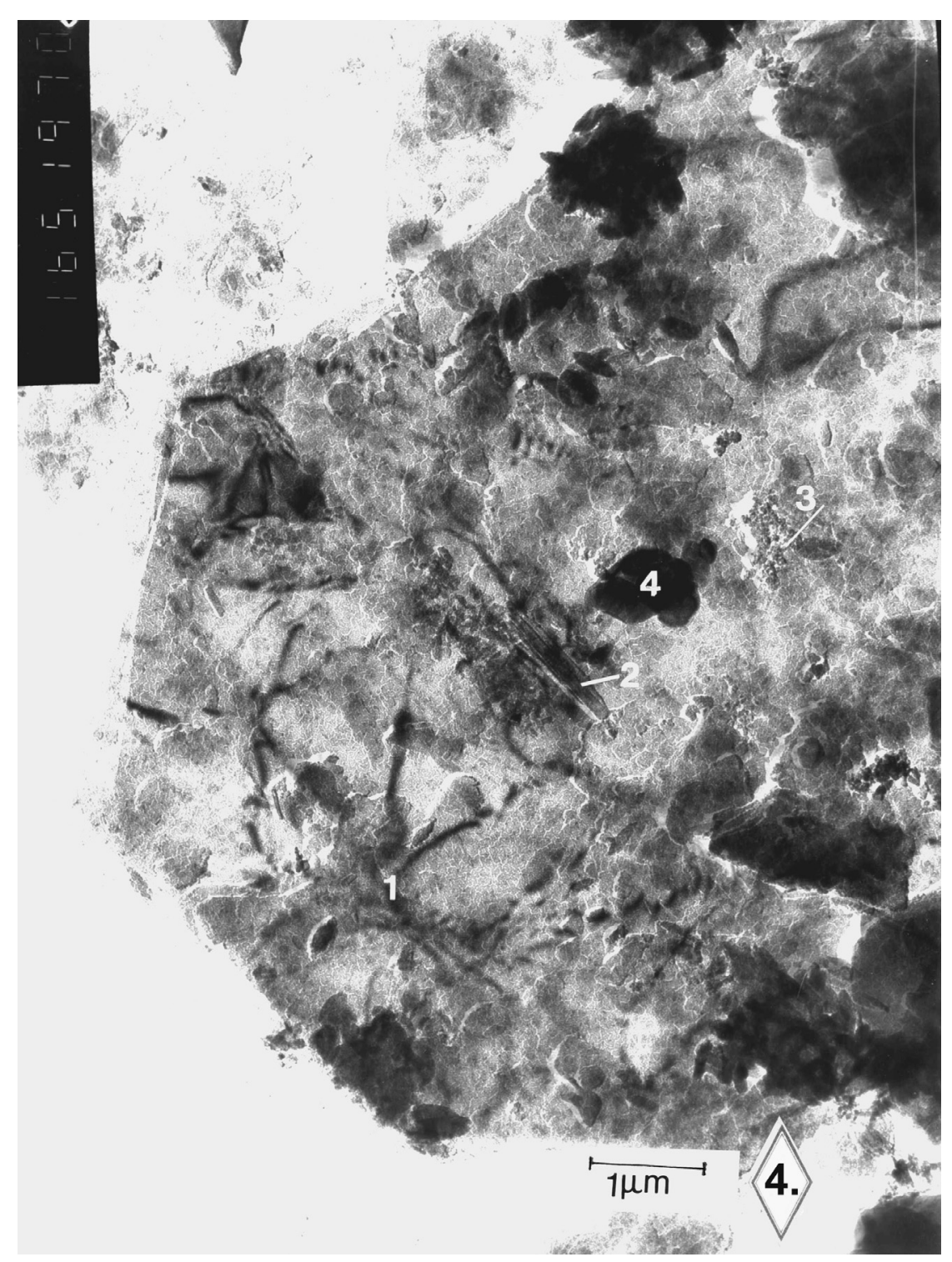

4. ábra

1. TEM-felvétel

A 4. ábrán muszkovit látható. Egymáson elcsúszott lemezek, az éleken kezdődő mállás. Kikucsi vonalak (1). A japán szerző írta le először, hogy a kristályosodás hibahelyein az elektronsugarak elhajlanak, és láthatóvá teszik azokat. A jelenség a csillámcsoport ásványaira jellemző, ezért diagnosztikai lehetőséggel is bír. 2. Halloysit. 3. Vas-mangán mikrokonkréciók. 4. Kaolinit és nem meghatározható töredékek az eredeti kristálylapra rakodva. 


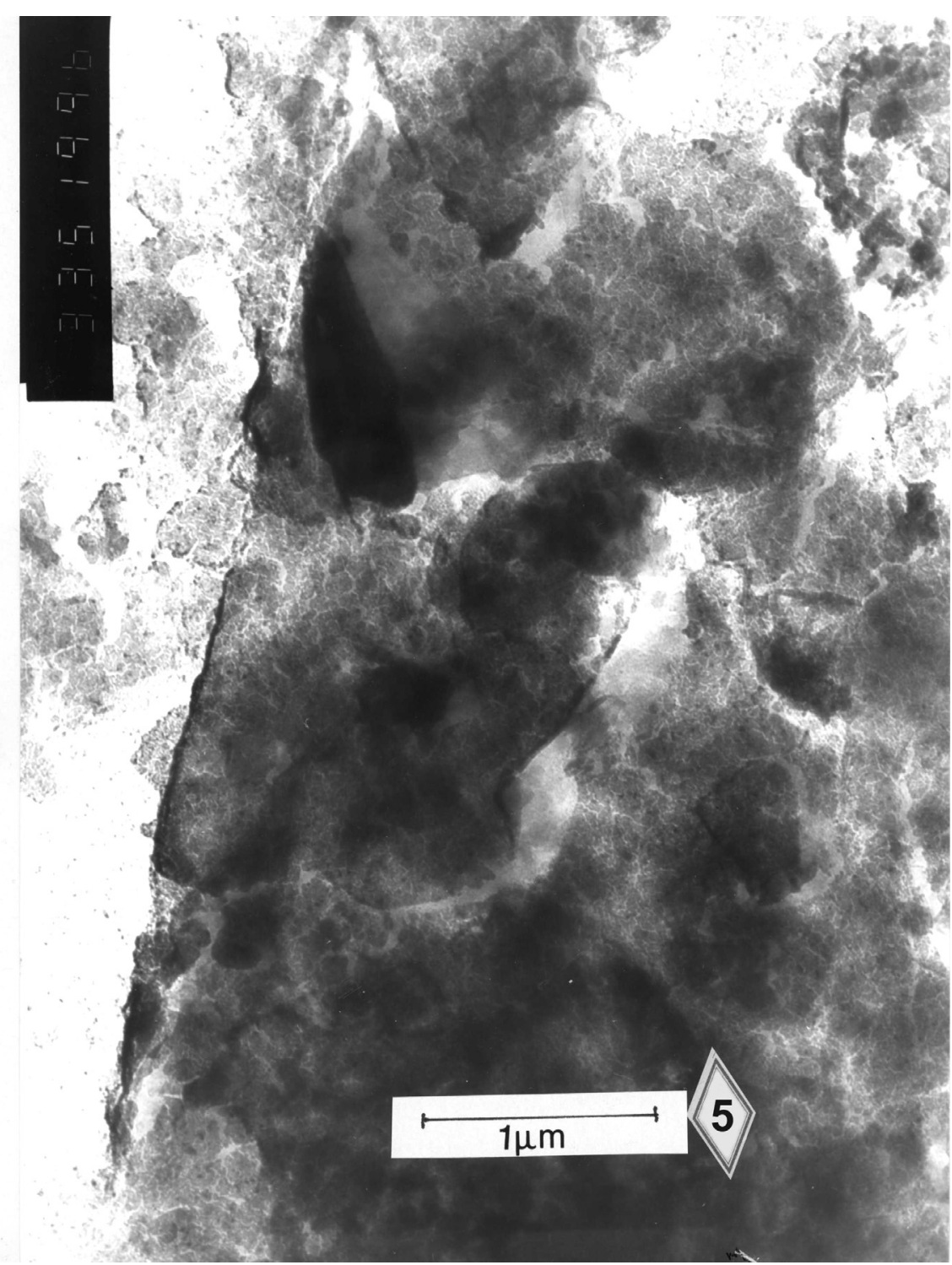

5. ábra

\section{TEM-felvétel}

Nagy mállott ásvány látható az 5. ábrán. A degradáció a kristályosodási hibahelyeknél kezdődött. Erre mutatnak a haránt irányban megindult folyamatok is. Az eredeti kristálylapra törmelék rakódott, melyben a mállás és a képződés végtelen variációival találkozunk. Így a valós történés és forma nem határozható meg. 


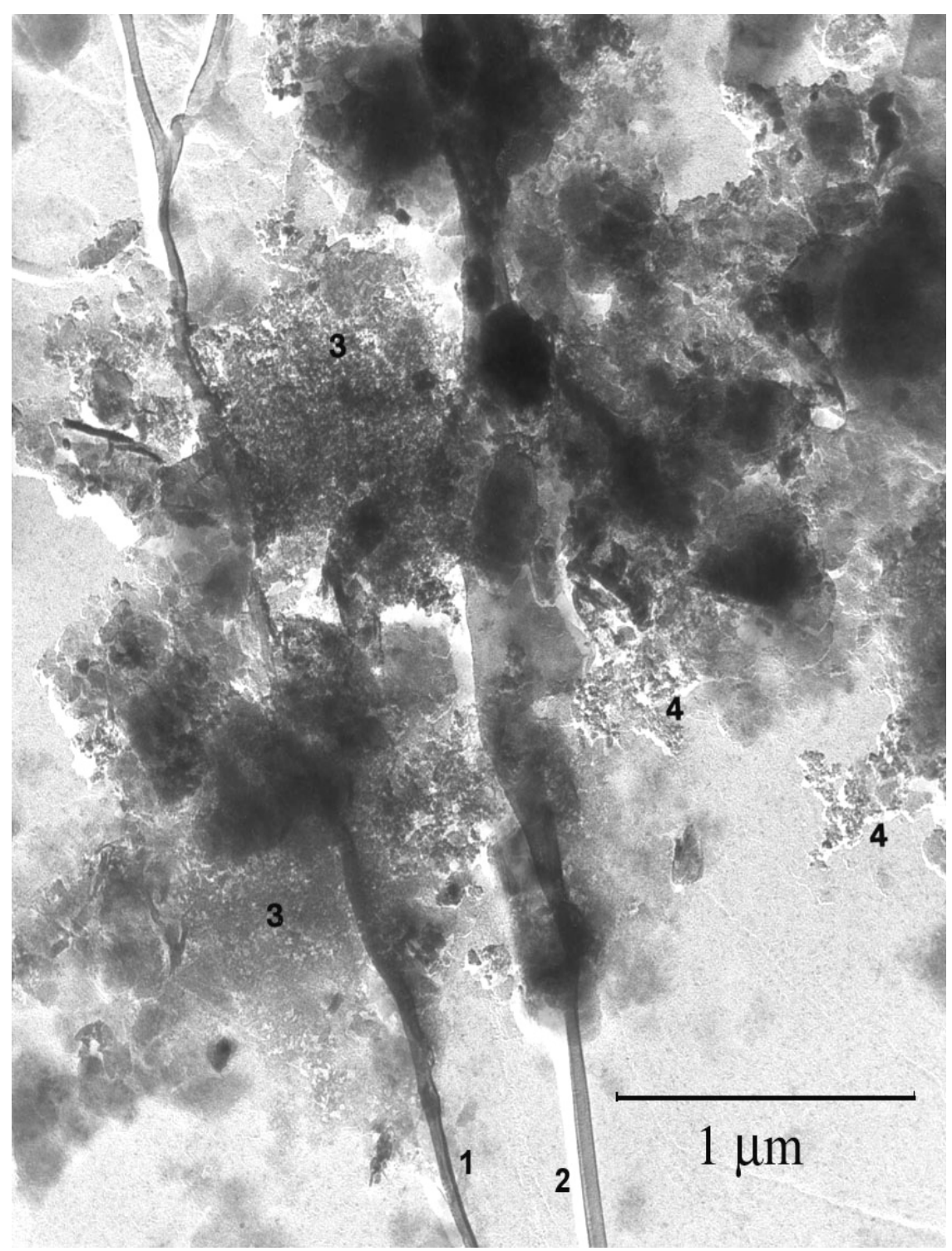

6. ábra

\section{TEM felvétel}

Hordozó hártya gyürődése, műtermék (1-2). A felvétel jellemzője vas-szulfid (3) és vasmangán mikrokonkréció (4) (PÁRTAY, 1981) kristályos és amorf részek között. A felvételen az amorf szilikát elhelyezkedése az erősen mállott környezetben láthatóvá teszi az ásványtársulások, ásványképződések létrejöttét. Bár képződésük időintervalluma csak egy pillanatát teszi lehetővé a megismerésnek. 
KUELLNER (1959, cit. VICZIÁN (1986)) szerint a Na- és K-dús fázisok egymáshoz viszonyított mennyiségi aránya jól becsülhető a 201 index albit reflexió $(\mathrm{d}=$ $0,403 \mathrm{~nm})$ és a 201 index ortoklász reflexió $(\mathrm{d}=0,422 \mathrm{~nm})$ segítségével. Ezek intenzitásviszonya a két fázis arányának függvénye.

A kezeletlen talajt jellemző porminták ásványi összetétele széles spektrumú, nevezetesen:

$\begin{array}{ll}\text { montmorillonit } & \text { kvarc } \\ \text { illit } & \text { ortoklász } \\ \text { klorit } & \text { plagioklász } \\ \text { csillám } & \text { goethit } \\ \text { rendezett és rendezetlen } & \text { böhmit } \\ \text { szerkezetü közberétegződések } & \text { klinoptilolit }\end{array}$

Néhány ásványt (GIESEKING, 1975), közberétegzett szerkezetet irodalmi adatok alapján azonosítottunk. Ezek a következők:

- Cserélhető $\mathrm{K}^{+}$-ion esetében montmorillonitban csak egy, $\mathrm{H}^{+}$-ion esetében pedig két vízmolekula réteg helyezkedik el. Ebben az esetben a periódus c irányban $1,45 \mathrm{~nm}$, etilénglikolos hatásra $1,70 \mathrm{n}$, végül $550{ }^{\circ} \mathrm{C}$-on 9,94-9,98 nm (NEMECZ, 1973).

- Rendezetlen illit-montmorillonit, 80\%-os dioktaéderes illit komponenssel: a három legerősebb csúcs:

$\begin{array}{lll}1,1 & \mathrm{~nm} & \mathrm{VS} \\ 0,256 & \mathrm{~nm} & \mathrm{MS} \\ 0,150 & \mathrm{~nm} & \mathrm{MS}\end{array}$

Jelölések: VS: nagyon erős (very strong); MS: közepesen erős (middle strong); S: erős (strong) (Bocchi \& Morandi, 1969; cit. THOREZ, 1975).

- Rendezett dioktaéderes kevert rácsszerkezetű klorit-montmorillonit a három reflexió :

$\begin{array}{lll}2,98 \mathrm{~nm} & 10 & 001 \\ 1,47 \mathrm{~nm} & 15 & 002 \\ 0,98 \mathrm{~nm} & 20 & 003\end{array}$

(Sudo, 1954; cit. Brown, 1961; cit. THOREZ, 1975).

- Rendezett csillám-montmorillonit (csillám 0,6; montmorillonit 0,4)

a két legerösebb reflexió:

$$
\begin{array}{ll}
2,75 \mathrm{~nm} & 250 \\
1,27 \mathrm{~nm} & 200
\end{array}
$$

(Shimoda \& Sudo, 1969; cit. THOREZ, 1975).

- Alumínium-dioktaéderes montmorillonit-klorit kevert rácsszerkezet

$\begin{array}{lllll}\text { a négy legerösebb reflexió } & 3,00 & \mathrm{~nm} & 16 & 001\end{array}$

$1,50 \mathrm{~nm} \quad 24 \quad 002$

$0,986 \mathrm{~nm} \quad 49 \quad 003$

$0,496 \mathrm{~nm} \quad 19 \quad 006$

(SUDO \& KODAMA, 1957).

- Részlegesen rendezett csillám-montmorillonit kevert rácsszerkezet

$\begin{array}{lllll}\text { a legerösebb három reflexió } & 2,52 & \mathrm{~nm} & 30 & 001 \\ & 1,130 & \mathrm{~nm} & 100 & 002 \\ & 0,324 & \mathrm{~nm} & 35 & 007\end{array}$

(HAMILTON, 1967). 
$-\mathrm{Na}-\mathrm{Ca}$ montmorillonit (természetes)

$\begin{array}{llll}\text { a reflexiók } & 1,585 \text { és } 1,405 \mathrm{~nm} & \mathrm{VS} & 001 \\ & 0,313 \text { és } 0,305 \mathrm{~nm} & \mathrm{~S} & 005 \\ 0,1502 \mathrm{~nm} & \mathrm{~S} & \text { nem közölt }\end{array}$

(Alietti \& Alietti, 1962; cit. THOREZ, 1975).

A RTG vizsgálataink értékelése a következö kísérleti rend szerint történt: A 0, 25 és $50 \%$-os földpátkezelések közül a növénnyel beállított kezdő A-sorozat $(1 \mathrm{~N}, 2 \mathrm{~N}$ és $3 \mathrm{~N}$ ) és az utolsó $\mathrm{C}$-sorozat $(7 \mathrm{~N}, 8 \mathrm{~N}$ és $9 \mathrm{~N})$, ill. növény nélküli 1,2 és 3 kezeléseket vontuk be a vizsgálatokba. Így tehát megvizsgáltuk a növényes minták gyökérközegében a kezdeti és végállapotot, valamint a növény nélküli kezelések felső és alsó szintjei talajában létrejövő változásokat. A továbbiakban az $\mathrm{A}+\mathrm{A}$ plagioklászt, az $\mathrm{O}$ ortoklászt jelent. A csúcsmagassági értékek 001 rendủek.

A RTG vizsgálatok eredményei alapján a következö megállapitásokat tettük:

$1 \mathrm{~N}$ és $7 \mathrm{~N}$ (földpát: $0 \%$ ): Az $1 \mathrm{~N}$ rizomonolit talajára jellemző, hogy az ásványi összetétel a felső és az alsó szintben nem változott. A 7N monolitban (két tesztnövény nemzedék után vett mintában, lásd 2 . táblázat) a röntgenamorf rész megnőtt. $\mathrm{A}$ rizomonolitokban az A+A-O arány közel azonos maradt. A csúcsmagasság 14-15.

$2 \mathrm{~N}$ és $8 \mathrm{~N}$ (földpát: $25 \%$ ): A $2 \mathrm{~N}$ rizomonolit talajának felső rétegéből vett minta megnövekedett amorf részt mutat. Az alsó mintavételben ennek az összetevőnek a mennyisége lecsökken az $1 \mathrm{~N}$ rizomonolit szintjére. Az ásványi összetevőkben nincs változás. $\mathrm{A}$ felső szintben az $\mathrm{A}+\mathrm{A}-\mathrm{O}$ csúcsmagasság 16-34, az alsó mintában az arány megfordul $\mathrm{A}+\mathrm{A}-\mathrm{O}=24-18$.

A $8 \mathrm{~N}$ rizomonolitban mindkét mintavételi helyen az A+A-O csúcs 16-20. Az amorf rész csökkenést mutat mindkét mintavételi helyen. Az ásványi összetétel változatlan.

$3 \mathrm{~N}$ és $9 \mathrm{~N}$ (földpát: $50 \%$ ): A $3 \mathrm{~N}$ rizomonolit talajában sok a közberétegződés. Sok olyan reflexió mérhető, melyek a kisebb földpáttartalmú kezelésekben a kimutathatósági határ alatt voltak. A felső rétegben az A+A-O csúcsmagasság 25-36; az alsóban 25-28. A $9 \mathrm{~N}$ rizomonolit talajában a legfeltünőbb, hogy az amorf vonal elsimult és közelít az alapvonalhoz. A felső és alsó mintában az A+A-O nagymértékben eltolódott: $25-55$. Ebben az 50\% földpátot tartalmazó kezelésben egymás után két kukoricanemzedéket neveltünk fel virágzásig (lásd 1. táblázat), ami miatt jelentősen - kétszeresére - nőtt a vizsgált tényezők egymásra hatásának időtartama.

Összefoglalva:

- A földpát-kezeletlen mintában a mért periódus alatt nem történt szignifikáns változás.

- A 25\% földpát-terhelésủ mintában a röntgenamorf anyag mennyiségi növekedése gyökérhatásnak tulajdonítható.

- Az 50\%-os terhelésü mintában gyökérhatást nem mutattunk ki, lehetséges, hogy ez a koncentrációarány már nem kedvez a gyökéraktivitásnak (l. gyökérsürüség-adatok), ugyanakkor tartamhatás érvényesülhet. A közberétegződések száma emelkedett. Az amorf anyagé jelentősen csökkent. Ez bizonyos fokú rendeződést jelent. 
- A növény nélkül érlelt monolitokban az amorf rész az alsó mintában csökken, mindhárom kezelésben. A mérhető csúcsok száma a legnagyobb mértékben a legnagyobb földpátadag hatására növekedett $(0<25 \%<50 \%$ földpátkezelés).

Ez a mérési mód jó közelítést ad az amorf anyag csökkenése, a különbözö terhelések, a mintavételi szintek és a mérhető csúcsok számának növekedése között. A mérés $2^{\circ}-62^{\circ}$ két tetában határok között történt (6. táblázat).

\section{6. táblázat}

A mérhető csúcsok száma és a plagioklász-ortoklász arány $(\mathrm{A}+\mathrm{A}-\mathrm{O})$ a növény nélküli kezelésekben

\begin{tabular}{|c|c|c|c|c|}
\hline \multirow{2}{*}{$\begin{array}{c}\text { Földpát- } \\
\text { adag, } \\
\%\end{array}$} & \multicolumn{2}{|c|}{ Mérhető csúcsok száma } & \multicolumn{2}{c|}{$\begin{array}{c}\text { (5) } \\
\mathrm{A}+\mathrm{A}-\mathrm{O}\end{array}$} \\
\cline { 2 - 5 } & $\begin{array}{c}(3) \\
\text { Felső szint }\end{array}$ & $\begin{array}{c}(4) \\
\text { Alsó szint }\end{array}$ & $\begin{array}{c}\text { (3) } \\
\text { Felső szint }\end{array}$ & $\begin{array}{c}\text { (4) } \\
\text { Alsó szint }\end{array}$ \\
\hline 0 & 32 & 32 & $10-$ nem mérhető & $8-5$ \\
25 & 36 & 44 & $15-15$ & $10-20$ \\
50 & 46 & 51 & $20-50$ & $40-50$ \\
\hline
\end{tabular}

Külön vizsgáltuk a montmorillonit társulásainak viszonyát. Azt tapasztaltuk, hogy a leggyakoribb közberétegződés a montmorillonit-illit formáció. Nagyok az összetevők mennyiségi variációi. A társulásokban több a rendezetlen, mint a rendezett illit szerkezet. A rendezetlenség növekedésének oka lehet - a mesterségesen elóállított - magas káliumszint. Ha az egyéb feltételek adottak, a K-felesleg részvételével létrejöhetnek olyan ad hoc szerkezetek, melyeknek szabad töltésfeleslege lehetővé teszi részvételüket közberétegződés kialakulásában. Az A+A és O mennyiségi viszonyának az ortoklász irányában történő elmozdulásának okát is ebben látjuk. A 3. táblázatban bemutatott vízoldható K-értékek megoszlása a talaj-földpát keverékek felső és alsó rétegei között összhangban van a röntgendiffrakcióval kimutatott ásvány-átalakulásokkal. Mennyiségileg a következő társulás a montmorillonit-csillám és a montmorillonit-klorit rétegződés. A leírtakon kívül a mintában még meghatároztunk vas- és nátrium-montmorillonitot is.

Néhány ortoklászőrlemény mintában, klorittól jól elkülöníthetően, kaolinitet azonosítottunk. Véleményünk szerint az ortoklászörleményből felszabaduló elemek kölcsönhatásba lépve a hibahelyeknél összeköthetik a röntgen számára addig fel nem ismerhető részeket.

\section{Összefoglalás}

A talajból és természetes ásványból feltáródó kálium forgalmát - elsősorban az ásványi összetételre gyakorolt hatásait - tanulmányoztuk gyökérközegben, valamint gyökérhatás nélkül, azonos feltételek között kezelt talajban. Megvizsgáltuk a bánya- 
termék ortoklászőrlemény hatását a talajra, a kukorica gyökérsürüségére és Kfelvételére, valamint az agyagásványokra.

Nagyadagú földpátkezelés hatására a kukorica gyökérsűrüsége jelentősen csökkent, míg K-felvétele nőtt.

A montmorillonit társulásainak viszonyát tanulmányozva azt tapasztaltuk, hogy a kísérleti talajban leggyakoribb közberétegződés a montmorillonit-illit formáció. A társulásokban több a rendezetlen, mint a rendezett illit szerkezet. A rendezetlenség növekedésének oka lehet a mesterségesen elóállított magas káliumszint. Ha az egyéb feltételek adottak, a K-felesleg részvételével létrejöhetnek olyan ad hoc szerkezetek, melyeknek szabad töltésfeleslege lehetővé teszi részvételüket közberétegződés kialakulásában. Az plagioklász $(\mathrm{A}+\mathrm{A})$ és ortoklász $(\mathrm{O})$ mennyiségi viszonyának az ortoklász irányába történő elmozdulásának okát is ebben látjuk. Mennyiségileg a következő társulás a montmorillonit-csillám és a montmorillonit-klorit rétegződés. A leírtakon kívül a mintában még meghatároztunk vas- és nátriummontmorillonitot is.

A kukorica gyökérkörnyezetéből származó mintában a 25\%-os ortoklászterhelésnél a röntgenamorf rész mennyisége jelentősen növekedett. Ezt a jelenséget gyökérhatásnak tulajdonítjuk.

A pásztázó elektronmikroszkóp (PEM) és transzmissziós elektronmikroszkópos (TEM) vizsgálatokkal, különböző technikák alkalmazásával, az archívumunkból kiválasztott néhány példán bemutattuk azokat a topográfiai és fizikai változásokat, mállás és újraképződés egy pillanatát, melyek a különböző ásvány-alakulatokat létrehozzák.

Kulcsszavak: talajásványok, kálium-migráció, káliumföldpát, gyökérhatás, RTGPEM-TEM

A fenti kutatást az Országos Tudományos Kutatási Alap a T 035274 sz. szerződés keretében támogatta.

\section{Irodalom}

BeutelsPaCher, H. \& VAN DER MALER, H., W., 1968. Atlas of Electronmicroscopy of Clay Minerals and Their Admixtures. Elsevier Publishing Company. AmsterdamLondon-New York.

BuZÁs I., et al., 1998. A talajok fizikai-kémiai és kémiai vizsgálatára használt fontosabb kémiai és müszeres analitikai eljárások elvi és módszertani alapjai. In: Talajés agrokémiai vizsgálati módszerkönyv 2. A talajok fizikai-kémiai és kémiai vizsgálatának módszerei. (Szerk: BuZÁs I.) 64-74. Mezőgazdasági Kiadó. Budapest.

CsiLlaG J. et al., 2005. K-földpát, savkezelés és száradás-nedvesedés hatása a talajoldat kálium koncentrációjára Agrokémia és Talajtan. 54. 121-138.

DóDONY I., 1993. Transzmissziós elektronmikroszkópos (TEM) vizsgálatok. In: Talaj és agrokémiai vizsgálati módszerkönyv I. (Szerk: BuZÁs I.) 281-291. INDA 4231 Kiadó. Budapest.

FredericKson, A. F., 1951. Bull. Geol. Soc. Amer. 62. 221. 
GiEseKInG, J. E., 1975. Soil Components. Vol. 2. Inorganic Components. SpringerVerlag. Berlin-Heidelberg-New York.

HAmilton, J. D., 1967 Partially ordered mixed-layer mica-montmorillonite from Maitland, New South Wales. Clay Min. 7. 63-78.

HeNNING, K. H. \& STÖRR, M., 1986 Electron Micrographs (TEM, SEM) of Clays and Clay Minerals. Akademic Verlag. Berlin.

HINSINGER, P., 1998. How do plant roots acquire mineral nutrients? Chemical processes involved in the rhizosphere. In: Advances in Agronomy. (Ed: STEWART, B. A.). Vol. 64. 225-265. Academic Press.

KANT, S., KANT, P. \& KAFKAFI, U., 2005. Potassium uptake by higher plants: from field application to membrane transport. Acta Agron. Hung. 53. 443-459.

KÁlmÁN A., 1993.Talajok röntgendiffrakciós fázisanalízise. In: Talaj és agrokémiai vizsgálati módszerkönyv I. (Szerk: BuZÁs I.) 293-314. INDA 4231 Kiadó. Budapest.

KocH S., 1985. Magyarország ásványai. Akadémiai Kiadó. Budapest.

KocH S. \& SzTRÓKAY K., 1967. Ásványtan II. Tankönyvkiadó. Budapest.

KUELLNER, F. J., 1959. X-ray intensity mesurements on perthitic materials. I. Theoretical considerations. J. Geol. 67. (6) 648-660.

LuKÁCs, A., PÁRTAY, G. \& VÉGH, K. R., 2005. Measurements of $\mathrm{CO}_{2} / \mathrm{O}_{2}$ concentrations in the gas phase of soil-plant system in potassium feldspar treated sandy soil. Cereal Res. Commun. 33. 263-267.

NeMECZ E., 1973. Agyagásványok. Akadémiai Kiadó. Budapest.

PÁRTAY G., 1971. A talajt alkotó ásványok keletkezése és átalakulása. Agrokémia és Talajtan 20. 401-410.

PÁRTAY G., 1973. Hazai tapasztalatok az elektronmikroszkóp alkalmazásának lehetőségeiről a talajtani vizsgálatokban. Agrokémia és Talajtan. 22. 389-399.

PÁRTAY G., 1980. Pásztázó elektronmikroszkóp és energia-szóródásos röntgen mikroanalízis alkalmazása talajok vizsgálatában. Agrokémia és Talajtan. 29. 545566.

PÁRTAY, G., 1981. Scanning electronmicroscopy study of Fe-Mn concretions in soil. Zeitschrift für Microscopie. 20. Wien. 32-34.

PÁRTAY G., 1993. Pásztázó elektronmikroszkópos (PEM) vizsgálatok. In: Talaj és agrokémiai vizsgálati módszerkönyv I. (Szerk: BUZÁs I.) 256-280. INDA 4231 Kiadó. Budapest.

RÉDLY L.-NÉ, 1998. A talajok kationcserélő tulajdonságainak meghatározási módszerei. In: Talaj- és agrokémiai vizsgálati módszerkönyv 2. A talajok fizikai-kémiai és kémiai vizsgálatának módszerei. (Szerk: BuZÁs I.). 103-136. Mezőgazdasági Kiadó. Budapest.

SPARKS, D. L., 1987. Potassium dynamics in soils. In: Advances in Soil Science. (Ed: StewART, B. A.) 6. 2-63. Springer Verlag. New York.

SPARKS, D. L. \& HUANG, P. M., 1985. Physical chemistry of soil potassium. In: Potassium in Agriculture. (Eds: MunSON, R. D. et al.). 201-276. SSSA. Madison. Wisc. USA.

Srinivasa RaO, Ch., Subba RaO, A. \& RuPA, T. R., 2000. Plant mobilization of soil reserve potassium from fifteen smectite soils in relation to soil test $K$ and mineralogy. Soil Sci. 165. 578-586. 
Sudo, T. \& KodAma, H., 1957. An aluminian mixed layer of montmorillonite-chlorite. Zeits. Krist. 109. 379-387.

Sutcliffe, J. F., \& Dennis, A. B., 1981. Plants and Mineral Salts. Studies in Biology. 48. Edward Arnold Ltd. GB.

SzENDREI G., 1994. Talajásványtan. Ecoplan. Budapest.

Thorez, J., 1957. Phyllosilicates and Clay Minerals. Lelotte. Dison. Belgium.

VÉGH, K. R. \& FÜLEKY, GY., 2004. Potassium uptake and dynamics in rhizosphere as affected by drought. In: Proc. III. Alps-Adria Scientific Workshop, Dubrovnik, 16 March 2004. 363-367.

VICZIÁN I., 1986. Röntgendiffrakciós ásványhatározás. Módszertani Közlemények. MÁFI. Budapest.

Érkezett: 2006. március 13. 


\title{
Potassium Migration in Root Medium Treated with Potassium Feldspar
}

\author{
G. PÁRTAY, K. RAJKAI-VÉGH and A. LUKÁCS \\ Research Institute for Soil Science and Agricultural Chemistry (RISSAC) of the \\ Hungarian Academy of Sciences, Budapest
}

\section{Summary}

The main processes that define $\mathrm{K}$ dynamics in the soil-plant system include the weathering of K-bearing minerals, the release and fixation of $\mathrm{K}$ in the soil, and the $\mathrm{K}$ uptake by plant. Among other soil factors, mineralogy is known to influence the availability of $\mathrm{K}$ in the soil.

The dynamics of potassium released from the soil and from $\mathrm{K}$ minerals with slowrelease characteristics (feldspars) and the effects of its migration on soil minerals were studied in a soil-plant system.

The laboratory studies were carried out with mixtures of potassium- $(80 \%)$ and sodium- $(20 \%)$ feldspars (of Norwegian origin) ground to $100 \mu \mathrm{m}$ to serve as potassium source in a rhizomonolith experiment. The experimental soil was collected from the 10 to $20 \mathrm{~cm}$ surface layer of a slightly acidic sandy soil from Somogysárd. The soil was air-dried, ground to pass a $2 \mathrm{~mm}$ sieve and mixed with the feldspar. $500 \mathrm{mg}$ superphosphate per $\mathrm{kg}$ soil was added as fertilizer. A $15 \times 15 \times 35 \mathrm{~cm}$ clear plexiglass container (to study root development) was filled with $15 \mathrm{~cm}$ quartz sand at the bottom, then with $4 \mathrm{~kg}$ soil or soil-feldspar mixture, passed through a $1.6 \mathrm{~mm}$ sieve, and finally with $6 \mathrm{~cm}$ quartz sand at the top. Three treatments were used (relative to the total soil amount): $0 \%$ feldspar, 25\% feldspar and 50\% feldspar. Maize (Zea mays L.) was used as test plant. Five seeds were sown into each column and the plants were grown to maturity. Potassium-free macro- and micronutrient solutions were applied to the soil regularly.

Clay mineral studies were made by X-ray diffraction (RTG). Earlier results observed by scanning electron microscopy (PEM) and transmission electron microscopy (TEM) were used to demonstrate the weathering and formation of various mineral associations.

Illite-montmorillonite was found as the most frequent interstratification among montmorillonite associations. The disordered structure of illite prevailed over the ordered structure in samples treated with $50 \%$ feldspar due to the very high potassium level. The random formation of structures with excess positive free ionic charges may favour interstratification.

It was hypothesized that 1 . the plant-induced weathering of feldspars (orthoclase) is significant in the rhizosphere, 2. High rates of $\mathrm{K}$ application affect $\mathrm{K}$ release and fixation, and 3. the fate of the minerals associated with the feldspars applied can be followed and their effect on $\mathrm{K}$ dynamics is detectable in the root environment.

A high rate of feldspar application reduced maize root length density while increasing K uptake.

Plant $\mathrm{K}$ uptake was much higher than the initial exchangeable $\mathrm{K}$ pool in the soil, and markedly reduced the amount of both water-extractable and exchangeable $\mathrm{K}$ in each feldspar treatment. 
Table 1. Main chemical and physical properties of the soil. Note: $\mathrm{H}=$ humus content; $\mathrm{T}$-value = cation exchange capacity; $\mathrm{KK}=$ amount of exchangeable potassium; $\mathrm{NKK}=$ non-exchangeable potassium; $<0.02 \mathrm{~mm}$ and $<0.002 \mathrm{~mm}$, weight $\%=$ clay + silt and clay contents, resp.; Tfs= bulk density.

Table 2. Treatments of the rhizomonolith experiment. (1) Feldspar rate. (2) Treatments without plants. (3) Treatments with plants; A, B, C = series of planted treatments.

Table 3. Particle size distribution of feldspar (\%). (1) Sample. a) Original sample; b) ground sample. (2) Particle size, mm.

Table 4. Element contents of the brown forest soil and the feldspar ground for 30 (a) or 60 (b) minutes. (1) Element; (2) $\mathrm{H}_{2} \mathrm{O}$-extractable element content in (3) Soil (4) Feldspar. (5) $\mathrm{HNO}_{3}$-extractable element content.

Table 5. Plant $\mathrm{K}$ uptake, water-extractable and exchangeable $\mathrm{K}$ at the end of the experiments (mg $\mathrm{kg}^{-1}$ soil-feldspar mixture). (1) Treatment; (2) $\mathrm{K}$ uptake by plant. (3) Kcontent of soil. (4) $\mathrm{H}_{2} \mathrm{O}$ extractable K. (5) Exchangeable K. (6) Treatment and soil layer: upper and lower. Remark: For treatments see Table 2.

Table 6. Number of detectable peaks and plagioclase:orthoclase $(\mathrm{A}+\mathrm{A}-\mathrm{O})$ ratio in treatments without plants. (1) Feldspar rate. (2) Number of detectable peaks. (3) Upper layer. (4) Lower layer. (5) Plagioclase:orthoclase ratio.

Fig 1. Orthoclase crystal.

Fig 2. PEM photograph No. 1. Cracked wall, weathered illite.

Fig 3. PEM photograph No. 2. Kaolinite and mica-illite conglomerate in a crotovina.

Fig 4. TEM photograph No. 1. Muscovite plate.

Fig 5. TEM photograph No. 2. Weathered mineral.

Fig 6. TEM photograph No. 3. Iron sulphide and Fe-Mn concretions. 